Акушерство та гінекологія

®С. В. Хміль, І. В. Корда, А. С. Хміль

ДВНЗ « Тернопільський державний медичний університет імені I. Я. Горбачевського МOЗ Украӥни»

Медичний центр «Клінікапрофесора С. Хміля»

\title{
КОМПЛЕКСНЕ ЛІКУВАННЯ ДИСПЛАЗІЇ ШИЙКИ МАТКИ ТА ПІХВИ НА ТЛІ ПАПІЛОМАВІРУСНОї ІНФЕКЦІї
}

КОМПЛЕКСНЕ ЛІКУВАННЯ ДИСПЛАЗІЇ ШИЙКИ МАТКИ ТА ПІХВИ НА ТЛІ ПАПІЛОМАВІРУСНОЇ ІНФЕКЦІї. У статТі представлено результати обстеження та лікування 126 жінок з дисплазією шийки матки на тлі папіломавірусної інфекції генітальної локалізації. Доведена ефективність проведення конізації шийки матки апаратом радіохвильової хірургії з подальшою лазерною коагуляцією післяопераційної рани та уражених стінок піхви, 3 використанням противірусної та імуномодулювальної терапії.

КОМПЛЕКСНОЕ ЛЕЧЕНИЕ ДИСПЛАЗИИ ШЕЙКИ МАТКИ И ВЛАГАЛИЩА НА ФОНЕ ПАПИЛЛОМАВИРУСНОЙ ИНФЕКЦИИ. В статье представлены результаты обследования и лечения 126 женщин с дисплазией шейки матки на фоне папилломавирусной инфекции генитальной локализации. Доказана эффективность проведения конизации шейки матки аппаратом радиоволновой хирургии с последующей лазерной коагуляцией послеоперационной раны и пораженных стенок влагалища с использованием противовирусной и иммуномодулирующей терапии.

INTEGRATED TREATMENT OF CERVICAL DYSPLASIA AND VAGINAL AGAINST HPV INFECTION. The paper presents the results of examination and treatment of 126 women with cervical dysplasia with papilloma virus infection of the genital localization. Efficiency of conisation of cervix by apparatus radiowave surgery followed by laser coagulation surgical wounds and infected vaginal walls, using antiviral therapy and imunostimulation has been proved.

Ключові слова: дисплазія шийки матки, папіломавірусна інфекція, лазерна коагуляція, радіохірургічна конізація.

Ключевые слова: дисплазия шейки матки, папилломавирусная инфекция, лазерная коагуляция, радиохирургическая конизация.

Key words: cervical dysplasia, papilloma virus infection, laser coagulation, radio surgical konisation.

ВСтУП. Серед онкозахворювань жіночих статевих органів частота злоякісного ураження шийки матки (ШМ) в Україні, за даними національного канцер-реєстру, посідає друге місце та реєструється на 100 тис. жіночого населення у 19 випадках [1]. Тому профілактика ракових захворювань жіночих статевих органів, особливо їх візуальних форм, для лікаря акушера-гінеколога завжди була, є і залишається першочерговим завданням.

В останні десятиліття внаслідок міграції та урбанізації населення констатовано збільшення захворювань, які передаються статевим шляхом, серед яких папіломавірусна інфекція (ПВІ) людини є однією 3 найпоширеніших [2, 3]. На сьогодні кількість інфікованих хворих у світі збільшилася більш ніж удесятеро. Основними клінічними проявами ПВІ $€$ аногенітальні бородавки та ураження ШМ, які спричиняють фізичний, психологічний і сексуальний дискомфорт $[4,5]$. Актуальність цієї патології зумовлена також тим, що вона входить до групи захворювань СНІД-асоційованого симптомокомплексу [6, 7], який вимагає особливої уваги до пацієнта [8], а також відомою онкогенністю вірусів штамів 16 та 18, які $€$ причиною значної частини злоякісних уражень шМ [9-12]. Нині серед жінок, які ведуть активне статеве життя (2035 років), ПВІ зустрічається у 30-50\%, а дисплазія шийки матки (ДШМ) - у $5 \%$.
Термін «дисплазія», запропонований J. W. Reagan у 1956 р. та затверджений Комітетом експертів ВООЗ у 1973 р., довго використовувався для усіх передпухлинних станів шийки матки. На даний час існує багато синонімів дисплазії: атипія, атипова гіперплазія, базальноклітинна гіперплазія, цервікальна інтраепітеліальна неоплазія (CIN). У 1988 році вчені-цитологи запропонували термін SIL (Squamous Intraepithelial Lesion - сквамозні інтраепітеліальні ушкодження), який $є$ зараз найпоширенішим [13].

Для діагностики дисплазії ШМ використовують цитологічне дослідження мазків, яке виявляє у хворих клітини з різним ступенем атипії. Одним з ранніх найвірогідніших методів виявлення мінімальних диспластичних змін сквамозного епітелію шийки матки $€$ РАР-тест (за Папаніколау). Він дозволяє достатньо ефективно виявляти передракові зміни епітелію цервікальні внутрішньоепітеліальні неоплазії різного ступеня важкості. Цей вид дослідження є обов'язковим для жінок, у яких виявлені зони зміненого епітелію при кольпоскопічному дослідженні шийки матки. РАР-тест інформативний у 60-90 \% випадків, проте не дозволяє повністю виключити ризик раку шийки матки. Лише за допомогою біопсії, місце якої визначають за допомогою кольпоскопії, встановлюють остаточний діагноз $[14,15]$. 


\section{Акушерство та гінекологія}

Найхарактернішими морфологічними ознаками дисплазії $є$ :

1) клітинна атипія (ядерний поліморфізм, гіперхромазія, стратифікація ядер, збільшення ядерно-цитоплазматичного індексу);

2) порушення диференціювання; зменшення або припинення продукції слизу клітинами епітелію;

3) порушення архітектоніки слизової оболонки (іррегулярна структура скрипт, проліферація і розгалуження залоз із формуванням поверхневих і внутрішньозалозистих сосочкових структур) [16-18].

Дисплазія шийки матки може зачіпати різні шари клітин плоского епітелію. Виділяють 3 ступені дисплазії шийки матки залежно від глибини патологічного процесу. Чим глибше уражений епітелій, тим важчий ступінь дисплазії шийки матки. За міжнародною класифікацією виділяють:

1. Легку дисплазію шийки матки (CIN I, дисплазія I) - зміни в будові клітин виражені слабо і зачіпають нижню третину багатошарового плоского епітелію.

2. Помірну дисплазію шийки матки (CIN II, дисплазія II) - зміни в будові клітин спостерігаються в нижній і середній третинах товщі плоского епітелію.

3. Важку дисплазію шийки матки або неінвазивний рак (CIN III, дисплазія III) - патологічні зміни зустрічаються у всій товщі епітеліальних клітин, але не поширюються на судини, м'язи, нервові закінчення, як при інвазивному раку шийки матки, який уражає i ці структури [13-15].

Перш ніж перейти до лікування хворої з дисплазією, обумовленою ПВІ, слід враховувати вираженість змін, вік та репродуктивні наміри пацієнтки. У 50 $60 \%$ випадків легка дисплазія самостійно регресує, а в інших випадках може стабілізуватись або прогресувати. При легкій дисплазії шМ, у разі виявлення урогенітальних інфекцій, проводиться динамічне спостереження і специфічне лікування. При помірній та тяжкій дисплазії проводять (електричну, лазерну, радіохвильову) конізацію шийки матки $[15,16]$.

Вивчення питань діагностики та лікування дисплазії шийки матки на тлі ПВІ незмінно залишається актуальним у проблемі охорони здоров'я жінки [1921]. Це зумовлено високою частотою злоякісних уражень шийки матки, що сягає 65-85 \% випадків ракового переродження геніталій. Тому безсумнівною $€$ необхідність лікування дисплазії шийки матки на фоні папіломавірусних уражень, що дозволить підвищити якість життя пацієнток та запобігти розвитку злоякісних новоутворень [22, 23]. Жоден із сучасних методів не приводить до повного вилікування та не гарантує відсутності рецидивів [24, 25]. Своєчасне та радикальне лікування дисплазії шийки матки на фоні ПВІ є одним з основних шляхів профілактики раку шийки матки [26]. Більшість методів, які застосовують, є місцевими і спрямовані на усунення зовнішніх проявів, а не на патогенетичні механізми захворювання [27]. Незважаючи на широке використання електрохірургічних методів лікування, які в останні 40 років знизили гостроту цієї проблеми, питання раціональної терапії залишається надзвичайно актуальним [2, 28, 29]. Принцип радикальності, оздоровлення хворих з дисплазія- ми ШМ передбачає: видалення патологічної ділянки ШМ за допомогою кріохірургії, діатермоконізації, деструкції дисплазії високоенергетичним лазером, висічення скальпелем [30, 32]. Крім недостатнього ефекту, можуть спостерігатись розвиток ендометріозу, значна лімфорея, тривала епітелізація і рубцева деформація ШМ, а також повторне виникнення дисплазії на фоні ПВІ [29, 33].

Окремі літературні повідомлення $€$ суперечливими [34-36], практично відсутні дані щодо динаміки дисплазії ШМ під впливом лікування на фоні ПВІ. Водночас ПВІ, яка є пусковим механізмом у виникненні дисплазії ШМ, та неадекватна реакція імунної системи можуть бути причиною рецидивів цієї патології [37, 38]. Системна реакція організму при дисплазії ШМ на вірус папіломи людини проявляється, насамперед, змінами з боку імунної системи, що $€$ недостатньо вивченим [39]. Ось чому наше дослідження присвячено вивченню дисплазії ШМ та стану імунної системи за ПВІ і ефективності лікувальної схеми, що поєднує як місцеві, так і загальні засоби впливу, що включають медикаментозну противірусну терапію і органозберігаючі методи хірургічних втручань. На сьогодні існує велика кількість наукових досліджень, які підтверджують ефективність застосування лазера в хірургічному лікуванні цілої низки гінекологічних захворювань [29, 32, 43, 13].

Завдяки унікальним властивостям лазерного променя у сучасній медицині досягнуто великих успіхів у лікуванні багатьох захворювань. Переломним моментом в Україні в останні десятиліття стало впровадження у клінічну практику напівпровідникових лазерів «Ліка-хірург», застосування яких має чимало переваг порівняно з традиційними методами лікування захворювань ШМ, піхви, вульви: діатермо- та кріодеструкцією, хімічними і консервативними методами:

- лазерний вплив здійснюється під контролем кольпоскопа, що дозволяє повністю прибрати вогнище ураження;

- утворюється лазерний струп, який при відторгненні не дає кровотечі;

- утворення на поверхні рани тонкої плівки, яка має бар'єрні та захисні властивості, що полегшує перебіг післяопераційного періоду та знижує ризик післяопераційних ускладнень;

- надійний контроль глибини випаровування та об'єму тканини, котру видаляють;

- мінімальне пошкодження тканин, розміщених під тканиною, яку випаровують або коагулюють;

- безкровність операції;

- відсутність післяопераційних грубих рубцевих змін, що особливо важливо при операціях на ШМ у жінок репродуктивного віку, в тому числі тих, які не народжували;

- високий рівень регенерації, відсутність стенозу, а також травматичності щодо шийкових залоз [40, 41].

Ефективність лазерних технологій пояснюється низкою ї переваг перед альтернативними методами оперативних втручань. Насамперед, лазери в хірургії дозволили здійснювати прицільно точний 
локальний вплив, адже, розсікаючи тканину, лазерний промінь одночасно коагулює кров на стінках розрізу. За рахунок цього зменшується крововтрата. Таким чином, застосування лазерів практично виконує давню мрію хірургів - можливість роботи на сухому операційному полі. Строго дозований вплив лазерного випромінювання забезпечує мінімальні пошкодження тканин, дозволяє проводити органозберігаючі операції. Лазерний коагуляційний некроз якісно відрізняється від некрозу, викликаного електрокоагуляцією або кріодеструкцією, тим, що його зона значно менша [43].

На нашу думку, найперспективнішим методом $€$ проведення конізації ШМ апаратом радіохвильової хірургії з подальшою лазерною коагуляцією післяопераційної рани та уражених стінок піхви лазерним апаратом «Ліка-хірург» (940 нм) потужністю від 10 до 25 Вт залежно від виду та локалізації патологічного процесу. Апарат не викликає глибокого ураження тканин та здійснює атравматичний розріз і коагуляцію тканин, забезпечуючи відсутність набряку та больових відчуттів після операції. Цей метод лікування особливо ефективний при ураженні стінок, передніх, задніх та бокових склепінь піхви папіломатозними розростаннями, а також при переході дисплазії ШМ на бокові склепіння.

Мета роботи - підвищити ефективність діагностики та лікування дисплазії шийки матки на тлі папіломавірусної інфекції шляхом розробки адекватних патогенетично обґрунтованих методів лікування дисплазії шийки матки.

МАТЕРІАЛИ ТА МЕТОДИ. Клінічне обстеження проводили на кафедрі акушерства та гінекології Тернопільського державного медичного університету ім. І. Я. Горбачевського, а також на базі Медичного центру «Клініка професора С. Хміля».

Було обстежено 126 жінок, 30 з яких - здорові, що сформували конрольну групу, а решта 96 - $з$ дисплазією ШМ на фоні ПВІ генітальної локалізації.

Залежно від проведеного лікування, пацієнтки були розподілені на 3 групи.

До першої групи включено 29 жінок, хворих на дисплазію ШМ на фоні ПВІ, яким проводили конізацію ШМ апаратом радіохвильової хірургії з подальшою лазерною коагуляцією післяопераційної рани та уражених стінок піхви лазерним апаратом «Лікахірург» (940 нм), потужність - від 10 до 25 Вт (залежно від виду та локалізації патологічного процесу).

До другої групи ввійшли 32 жінки, хворі на дисплазію ШМ на фоні ПВІ, яким проводили конізацію ШМ апаратом радіохвильової хірургії з подальшою лазерною коагуляцією післяопераційної рани та уражених стінок піхви апаратом «Ліка-хірург» (940нм, потужність - від 10 до 25 Вт) і які отримували лікування протефлазидом.

Третя група - 35 жінок, хворих на дисплазію ШМ на фоні ПВІ, яким проводили конізацію ШМ апаратом радіохвильової хірургії з подальшою лазерною коагуляцією післяопераційної рани та уражених стінок піхви апаратом «Ліка-хірург» (940 нм, потужність - від 10 до 25 Вт) і які отримували лікування протефлазидом і лафероном.
Операції проводили на 3-7-й день менструального циклу $з$ метою створення оптимальних умов для відновлення тканин та профілактики ендометріозу ШМ. Перед оперативним втручанням проводили знеболювання парацервікальним введенням 1 ампули убестезин форте (4 \% - 1,7 мл), додатково стінки піхви знеболювали анестезувальним спреєм «Лідокаїн» $10 \%$ та анестезувальним кремом «Емла».

Техніка проведення процедури.

1. За допомогою дзеркала Сімса оголювали та виводили ШМ.

2. ШМ та стінки піхви обробляли антисептичним розчином, витирали сухим стерильним ватним тампоном, після чого обробляли розчином Люголя. Йод має здатність забарвлювати клітини, багаті на глікоген, у коричневий колір. Патологічно змінені клітини, бідні на глікоген, йодом не забарвлюються і мають вигляд білих плям. Таким чином виділяли ділянки, які підлягають конізації та лазерній вапоризації.

3. Фіксували ШМ кульовими щипцями.

4. Проводили конізацію шМ радіохвильовим методом 3 подальшою коагуляцією післяопераційної рани за допомогою апарата «Ліка-хірург». При переході дисплазії шм на передні, задні та бокові склепіння, а також при ураженні стінок піхви папіломатозними розростаннями проводили місцеве знеболювання за допомогою анестезувального крему «Емла», після чого через 3-4 хвилини проводили лазерну вапоризацію апаратом «Ліка-хірург». Підведення лазерного променя до патологічної тканини здійснювали за допомогою кварцового світловода розфокусованим променем (відстань 0,1-0,2 мм до об'єкта). За період застосування лазерного апарата «Ліка-хірург» у нашій клініці при лікуванні патології ШМ та стінок піхви не було жодного випадку кровотечі.

У післяопераційному періоді пацієнткам з патологією ШМ на 9-11 днів призначали санацію піхви антисептичними розчинами (хлоргексидином, бетадином, мірамістином), а з метою поліпшення регенерації - вагінально метилурацилові свічки.

Незважаючи на високу інформативність сучасних методів дослідження ПВІ та патології ШМ, невід'ємною складовою частиною комплексного обстеження хворих є збирання та аналіз анамнестичних даних, для цього нами була розроблена картаанкета, куди ми вносили відомості стосовно менструальної та генеративної функцій, перенесених соматичних та гінекологічних захворювань, часу виявлення патології ШМ, якості й ефективності попереднього лікування. При комплексному обстеженні хворих звертали увагу на перенесені запальні захворювання придатків, вульви, ШМ, а також на такі скарги, як контактні кров'янисті виділення зі статевих шляхів, печію, біль, везикулярні висипання. Особливу увагу приділяли візуальному огляду зовнішніх статевих органів, виявленню папіломавірусних розростань на вульві та генітальній ділянці, проводили огляд за допомогою вагінальних дзеркал, при цьому визначали наявність папіломатозних розростань у ділянці вульварного кільця і стінок піхви, на форму і розміри ШМ, наявність поліпів, діля- 


\section{Акушерство та гінекологія}

нок лейкоплакії, макульозних змін слизової оболонки, старих розривів, ерозій різних форм. Брали мазки для бактеріологічного і бактеріоскопічного досліджень 3 цервікального каналу і піхви. Для виявлення вірусу папіломи людини високоонкогенних типів [23, 25, 38, 40, 42] використовували метод полімеразної ланцюгової реакції.

Для діагностики дисплазії та папіломавірусної інфекції використовували кольпоскопічне дослідження за методикоюЛ. М. Василевської, використовуючи відеокольпоскоп "Сканер-200» із звичайними світлофільтрами, при збільшенні 8-12-20 разів, та фронтальній відстані від об'єкта 210-240 мм. При кольпоскопії шийки матки визначали локалізацію $і$ характер процесу. Для виявлення більш чіткої кольпоскопічної картини проводили розширену кольпоскопію 3 використанням $3 \%$ розчину оцтової кислоти і розчину Люголя (проба Шіллєра), це дозволяло нам більш ефективно визначити локалізацію патологічного процесу для проведення більш точної лазерної деструкції, а також при кольпоскопії оцінювали колір слизової оболонки шийки матки, стан судинного малюнку, поверхню і рівень багатошарового плоского епітелію, стик багатошарового плоского і циліндричного епітелію (локалізація і характер), наявність і форму залоз, тип епітелію. Особливо звертали увагу на папіломатозні утворення, які локалізувалися в різних ділянках шийки матки та піхви.

Проводилось цитологічне дослідження мазків у пацієнток з першим - другим ступенем частоти піхвового вмісту. У пацієнток, які мали на шийці матки папіломатозні зміни та йоднегативні ділянки, де за допомогою цитологічного та кольпоскопічного методів дослідження було діагностовано дисплазію шийки матки, ознаки вірусного ураження, під контролем відеокольпоскопа проводили біопсію тканин шийки матки, (як мінімум дві ділянки).

Хворим призначали медикаментозну противірусну терапію: препарат «Протефлазид» призначався одночасно зовнішньо та всередину в краплях за відповідною схемою. У 20 мл ізотонічного розчину натрію хлориду розводили 2 мл протефлазиду, після чого на папіломи накладали примочки, а в піхву вводили просочений препаратом тампон 2-3 рази на добу протягом 20 днів. Одночасно із зовнішнім застосуванням препарат «Протефлазид» призначали всередину в краплях, по 10 крапель тричі на добу впродовж 30 днів.

Препарат «Лаферон» використовували місцево, для обколювання шийки матки, 2 рази на тиждень, по 3 млн ОД, на курс 10 процедур.

При взятті мазка на флору, за загальноприйнятою методикою, визначали кількість епітеліальних клітин, лейкоцитів, характер мікрофлори (палички Додерлейна, патогенна флора грамнегативні палички, коки, хламідії, ключові клітини, гриби, трихомонади), а також реакцію вагінального вмісту.

Усім проводили визначення показників загального імунітету - В- і Т-лімфоцитів та їх фракцій, імуноглобулінів. Для їх визначення використовували реакцію непрямої поверхневої імунофлюоресценції за допомогою моноклональних антитіл МKA IKO (ІКО-90 проти антигену СД-3 Т-клітин периферійної крові, МKA IKO-86 проти антигену СД-4, який наявний на субпопуляціїТ-клітин із хелперною функцією, MKA IKO-31 - антигену СД-8, що присутній на субпопуляціїТ-клітин із супресорною функцією, MKAІKO-12 - антигену СД-22 на клітинній поверхні В-лімфоцитів). Клінічні і лабораторні аналізи проводили до та після лікування.

РЕЗУЛЬТАТИ ДОСЛІДЖЕННЯ ТАЇХ ОБГОВОРЕННЯ. Розподіл хворих за віком та діагнозом показав, що основну кількість хворих склали жінки у віці від 18 до 45 років. Враховуючи роль статевих відносин як фактор ризику виникнення ПВІ, ми охарактеризували стан статевої сфери в обстежуваних нами хворих. У значної частини жінок початок статевого життя припадав на 15-17 років. Сексуальну функцію жінок характеризує не тільки вік початку статевого життя, а й кількість статевих партнерів. Отримання достовірних даних стосовно сексуального життя не завжди було можливим. Отримані нами результати обстеження свідчать, що раннє статеве життя та безладні статеві стосунки, часта зміна статевих партнерів, створює умови для виникнення сексуально-трансмісивних інфекцій та є частою причиною інфікування папіломавірусами людини.

У досліджуваних хворих ми порівнювали скарги. Більше половини хворих (80 \%) скаржилися на рясні виділення. Другою за частотою клінічною ознакою було свербіння і печія у піхві (52 \%). Відсутність скарг відмічено у $16 \%$ хворих.

Під час аналізу клінічних проявів різних патологічних процесів у піхві, асоційованих з ПВІ, не виявлено специфічних симптомів цього захворювання. За нашими даними, на перший план виступає симптоматика сексуально-трансмісивних захворювань статевих органів. Тривалість захворювання на ПВІ коливалась від 4 місяців до 10 років. Проте ці дані відносні, бо переважно хворі перебували під наглядом гінеколога несистематично.

3 анамнезу хворих відомо, що 70 \% лікувалися різними методами. Спектр застосування лікувальних заходів був дуже широким. Використовувалися як консервативні, так і деструктивні методи лікування. Серед інших найчастіше використовувалися методи діатермокоагуляції, деструкції папілом коломаком і солкодермом. Отримані дані свідчать, що методи, які ліквідовують морфологічні ознаки ПВІ, не забезпечують елімінацію вірусу папіломи у тканинах слизової оболонки та всього організму. Тому перед лікуванням необхідно проводити обстеження хворих на ДНК папіломавірусу людини, оскільки, залежно від типу вірусу, можливе виникнення злоякісної трансформації. Визначення типу вірусу та проведення відповідної пануючої противірусної терапії повинно значно підвищити ефективність деструктивних методів лікування та знизити кількість диспластичних захворювань ШМ, піхви, рецидивних кольпітів.

Підсумовуючи вищезазначене, необхідно підкреслити, що на ПВІ хворіють переважно молоді жінки активного репродуктивного віку. У більшої ча- 
стини хворих виділяють ранній початок статевого життя, велику кількість статевих партнерів, сексуально-трансмісивні захворювання, куріння, використання внутрішньоматкових та гормональних контрацептивів. Всі ці фактори становлять теоретичний і практичний інтерес, що дає можливість проводити низку профілактичних заходів з обмеження поширеності ПВІ, що сприятиме значному зменшенню кількості ракових процесів вульви та ШМ.

При аналізі системної реакції у пацієнток з дисплазією ШМ на фоні ПВІ було виявлено ознаки пригнічення імунної системи, переважно за рахунок ураження клітинної ланки імунітету (табл. 1).

Як видно з даних таблиці 1, спостерігалось достовірне зниження загальної кількості лімфоцитів, а при аналізі їх субкласів виявилось, що причиною цього є зменшення кількості С04-клітин, тоді як зменшення С08-клітин виявилося недостовірним. Порушення хелперної функції проявлялось і зниженням імунорегуляторного індексу, що, проте, було незначним.

Показники гуморального імунітету свідчили про його активацію, оскільки зростала кількість CD72клітин та імуноглобулінів усіх класів. Найсуттєвіше зростав рівень $\lg \mathrm{G}$, рівні імуноглобулінів інших типів зросли незначно.

Клінічна ефективність лікування ПВІ становила 68,96 \% у першій групі (20 осіб), дещо більше у II 78,12 \% (25 осіб) і була найвищою у III групі, де сягала $94,29 \%$ (33 особи).
Що стосується параметрів імунної системи, то позитивні зміни були аналогічними (табл. 2). Так, у I групі жінок, які отримували лише місцеве лікування, динаміка показників була незначною, а виявлені зміни статистично недостовірними, хоча загальна кількість Т-клітин (CD3) наближалась до показників контролю.

Зміни у II групі були більш вираженими, особливо стосовно гуморального імунітету. Спостерігалось достовірне зниження рівня $\lg \mathrm{G}$, порівняно з показниками до лікування, а решта показників суттєво не відрізнялися від контрольних.

Найкращим був ефект лікування у III групі жінок, хворих на дисплазію ШМ на фоні ПВІ, яким проводили конізацію ШМ апаратом радіохвильової хірургії з подальшою лазерною коагуляцією післяопераційної рани та уражених стінок піхви апаратом «Лікахірург» 940 нм, потужність - від 10 до 25 Вт) і які отримували лікування протефлазидом і лафероном. В даній групі хворих суттєво змінились усі найголовніші параметри імунітету - як клітинного, так і гуморального.

Так, зріс вміст CD3 та C04-клітин, зменшився усіх класів імуноглобулінів. Усі параметри не відрізнялись від аналогічних у контрольній групі.

Наші дані показують, що лише застосування противірусних препаратів дозволяє вплинути на патогенетичні механізми захворювання, що водночас забезпечує і кращий клінічний ефект. Місцеве ж лікування не впливає на систему імунітету і зумовлює лише зменшення місцевих проявів.

Таблиця 1. Показники імунної системи у жінок з дисплазією шийки матки на тлі папіломавірусної інфекції'

\begin{tabular}{|l|c|c|}
\hline \multicolumn{1}{|c|}{ Показник } & Контрольна група $(п=30)$ & Дослідна група (п=96) \\
\hline $\mathrm{CD} 3, \%$ & $52,5+1,34$ & $48,06 \pm 0,44^{*}$ \\
\hline $\mathrm{CD} 4, \%$ & $35,71 \pm 0,89$ & $32,41 \pm 0,28^{*}$ \\
\hline $\mathrm{CD} 8, \%$ & $16,79+0,71$ & $15,65 \pm 0,22$ \\
\hline $\mathrm{CD} 72, \%$ & $8,6 \pm 0,25$ & $9,42 \pm 0,19^{*}$ \\
\hline $\mathrm{CD} 4 \mathrm{CD} 8$ & $2,12 \pm 0,32$ & $2,07 \pm 0,25$ \\
\hline $\lg \mathrm{G}$, г/л & $9,18 \pm 0,89$ & $12,11+0,18^{*}$ \\
\hline $\operatorname{lq} \mathrm{A}$, г/л & $1,57+0,16$ & $1,9 \pm 0,08$ \\
\hline $\lg \mathrm{M}$, г/л & $2,89 \pm 0,36$ & $3,51+0,13$ \\
\hline
\end{tabular}

Примітка. *- різниця між показниками достовірна, $p<0,05$.

Таблиця 2. Вплив різних схем лікування на показники у жінок з дисплазією шийки матки на тлі папіломавірусної інфекції

\begin{tabular}{|c|c|c|c|c|c|}
\hline \multirow[b]{2}{*}{ Показник } & \multirow{2}{*}{$\begin{array}{c}\text { Контрольна група } \\
(n=30)\end{array}$} & \multirow{2}{*}{$\begin{array}{c}\text { До лікування } \\
(\Pi=96)\end{array}$} & \multicolumn{3}{|c|}{ Після лікування } \\
\hline & & & $\begin{array}{l}\text { I група } \\
(п=29)\end{array}$ & $\begin{array}{l}\text { II група } \\
(п=32)\end{array}$ & $\begin{array}{c}\text { III група } \\
(п=35)\end{array}$ \\
\hline CD3, \% & $52,5+1,34$ & $48,06 \pm 0,44^{*}$ & $49,12+1,22$ & $50,11+1,18$ & $51,78+1,14 "$ \\
\hline CD4, \% & $35,71 \pm 0,89$ & $32,41 \pm 0,28^{*}$ & $32,89 \pm 0,78^{*}$ & $33,54 \pm 0,68$ & $34,87 \pm 0,62^{* *}$ \\
\hline CD8, \% & $16,79+0,71$ & $15,65 \pm 0,22$ & $16,23 \pm 0,65$ & $16,57+0,61$ & $16,91+79$ \\
\hline CD72, \% & $8,6 \pm 0,25$ & $9,42 \pm 0,19^{*}$ & $9,11+0,65$ & $8,99 \pm 0,59$ & $8,69 \pm 0,41$ \\
\hline CD4/CD8 & $2,12 \pm 0,82$ & $2,07 \pm 0,25$ & $2,03 \pm 0,12$ & $2,02+0,11$ & $2,06 \pm 0,09$ \\
\hline $\lg \mathrm{G}$, г/л & $9,18 \pm 0,89$ & $12,11+0,18^{*}$ & $11,54+0,56^{*}$ & $10,87 \pm 0,49^{* *}$ & $9,54 \pm 0,47^{* *}$ \\
\hline $\lg A, г / л$ & $1,57+0,16$ & $1,9 \pm 0,08$ & $1,81 \pm 0,09$ & $1,74 \pm 0,08$ & $1,63 \pm 0,07^{\star *}$ \\
\hline ід М, г/л & $2,89 \pm 0,36$ & $3,51+0,13$ & $3,34 \pm 0,28$ & $3,09 \pm 0,21$ & $3,04 \pm 0,14^{* *}$ \\
\hline
\end{tabular}

Примітки:

1. * - різниця з контролем достовірна, $\mathrm{p}<0,05$.

2. ** - різниця 3 показниками до лікування достовірна, $p<0,05$. 


\section{Акушерство та гінекологія}

ВИСНОВКИ. 1. Дисплазія ШМ на фоні ПВІ супроводжується змінами з боку імунної системи, які характеризуються пригніченням клітинної ланки та активацією гуморальної.

2. Застосування радіохвильового методу для конізації ШМ 3 подальшою лазерною коагуляцією післяопераційної рани та уражених папіломами і дисплазією стінок піхви діодним лазером «Ліка-хірург» не впливає на параметри системного імунітету.

3. Для лікування дисплазії ШМ на фоні ПВІ peкомендовано поєднане застосування радіохірургічного апарата з подальшою лазерною коагуляцією післяопераційної рани та уражених папіломатозними розростаннями і дисплазією стінок піхви діодним лазером «Ліка-хірург», протефлазиду (місцево та всередину в краплях, по 10 крапель тричі на добу впродовж 30 днів) і лаферону для обколювання ШМ, 2 рази на тиждень, по 3 млн ОД, на курс 10 процедур.

4. Лазерна коагуляція післяопераційної рани та уражених папіломатозними розростаннями і полями дисплазії стінок піхви лазером «Ліка-хірург» дозволяє проводити мінімізоване органозберігаюче втручання, має виражений гемостатичний ефект, пришвидшує процеси репарації та регенерації.

5. У пацієнток з патологією ШМ на фоні ПВІ комплексний підхід до лікування значно покращує його результати.

ПЕРСПЕКТИВИ ПОДАЛЬШИХ ДОСЛІДЖЕНЬ. ПОдальші дослідження особливостей комплексного лікування дисплазії шийки матки з ураженням стінок піхви на тлі папіломавірусної інфекції дозволить розробити більш ефективні методи лікування та зменшити ймовірність рецидивів передракових станів та раку шийки матки.

\section{СПИСОК ЛІТЕРАТУРИ}

1. Рак в Україні, 2010-2011. Захворюваність, смертність, показники діяльності онкологічної служби // Бюл. нац. канцер-реєстру України. - К., 2012. № 13. - 124 c. Cancer in Ukraine 2010-2011. Morbidity, mortality, cancer service performance. Bull. National Cancer Registry of Ukraine, Kyiv, 13, $124 \mathrm{p}$.

2. Буданов П. В. Принципы лечения папилломавирусной инфекции / П. В. Буданов // Вопросы гинекологии, акушерства и перинатологии. - 2004. T. 3, № 6. - С. 70-75.

3. Киселев Ф. Л. Генетические и эпигенетические факторы прогрессии опухолей шейки матки / Ф. Л. Киселев // Вестн. Росс. АМН. - 2007. - № 11. C. 25-32.

4. Применение активатора противовирусного иммунитета в комплексной терапии рецидивирующих остроконечных кондилом / Ю. Н. Перламутров, А. М. Соловьев, Р. Р. Атауллаханов [и др.] // Иммунопатол. Аллергол. Инфектол. - 2003. - № 3.

5. Роговская С. И. Кондиломы гениталий, обусловленные папилломавирусной инфекцией / С. И. Роговская, В. Н. Прилепская, Е. А. Межевитинова // Русский медицинский журнал. - 1998. -№ 6 (5). - C. 309-311.

6. Garland S. M. Prevalence of sexually transmitted infections (Neisseria gonorrhoeae, Chlamydia trachomatis, Trichomonas vaginalis and human papillomavirus) in female attendees of a sexually transmitted diseases clinic in Ulaanbaatar, Mongolia / S. M. Garland, S. N. Tabrizi, S. Chen // Infect. Dis Obstet Gynecol. - 2001. - Vol. 9(3). - P.143-146.

7. Gilson R. J. S. Sexually transmitted infections / R. J. S.Gilson, A. Mindel // B.M.J. - 2001. - Vol. 322. P.1160-1164

8. Папіломавірусна інфекція та система інтерферону : монографія / Л. М. Лазаренко, М. Я. Співак,
О. М. Михайленко, Г. Т. Сухих. - К. : Фітосоціоцентр, 2005. - 288 c.

9. Cho N. H. Genotyping of 22 human papillomavirus types by DNA chip in Korean women: comparison with cytologic diagnosis / N. H. Cho, H. J. An, J. K. Jeong // Am. J. Obstet. Gynecol. - 2003. - Vol.188(1). - P. 5662.

10. De Villiers E.-M. Human pathogenic papillomavirus types: an update / Ed. H. zur Hausen // Human pathogenic papillomaviruses, Topics in Microbiology and Immunology, Berlin. -1994. - Vol. 186. - P. 1-13.

11. Hamidi A. E. Archival cervical smears: a versatile resource for molecular investigations / A. E. Hamidi, H. Liu, Y. Zhang // Cytopathology. - 2002. - Vol. 13(5). - P. 291-299.

12. Минкина Г. Н. Мониторинг цервикальных интраэпителиальных неоплазий // Глава в монографии В. Н. Прилепской «Патология шейки матки и генитальные инфекции». - М. : МЕДпресс-информ, 2008. - C. 48-52.

13. European Guidelines for Quality Assurance in Cervical Cancer Screening. Second edition - summary document / M. Arbyn, A. Anttila, J. Jordan [et al.] // Ann. Oncol. - Vol. 21(3). - 2010. - P. 448-458.

14. Sobin L. H. Global TNM advisory group. I L. H. Sobin, F. L. Greene Cancer. - 2004. - Vol. 100(5). - P. 1106.

15. Singer A. "Lower genital tract precancer. Colposcopy, pathology and treatment / A. Singer, J. M. Monaghan. - 2end ed. - Oxford (U.K.) : Blackwell, 2010.

16. Consensus guidelines for the management of women with cervical cytological abnormalities T. C. Wright, Jr. Cox, J. T. Massad [et al.] // JAMA. - 2002. - Vol. 287. - P. 2120-2129. 


\section{Акушерство та гінекологія}

17. Absence of dysplasia in the excised cervix by a loop electrosurgical excision procedure in the treatment of cervical intraepithelial neoplasia / A. Ryu, K. Nam, S. Chung [et al.] // J. Oncol. - Vol. 21(2). - 2010. - P. 87-92.

18. Репродуктивная эндокринология. - 2014 . № 3 (17). - С. 105-109.

19. Папилломавирусная инфекция как фактор репродуктивного риска (обзор литературы) / Н. М. Подзолкова, Л. Г. Созаева, Е. Н. Кошель [и др.] // Проблемы репродукции. - 2008. - № 1. - С. 18 21.

20. Трушина О. И. Роль папилломавирусной инфекции в генезе рака шейки матки / О. И. Трушина, Е. Г. Новикова // Российский онкологический журнал. - 2005. - № 1. - С. 45-51.

21. Методы ДНК-диагностики в диагностике инфекционных и воспалительных заболеваний в акушерстве и гинекологии / Ю. И. Бажора, В. В. Николаевский, М. Н. Лебедюк, В. П. Федчук // Актуальные вопр. инфектол. в акушерстве и гинекологии укр. секции ESIDOG. III Международный конгресс. Программа и тезисы работ. 1 - 2 июня 2000 года.- Одесca, 2000.- C. 49.

22. Молочков В. А. Папилломавирусная инфекция. Клиника, диагностика, лечение: пособие для врачей / В. А. Молочков, В. И. Киселев, И. В. Рудых. - М. : Издательский дом «Русский врач», 2004. - 35 с.

23. Сучасні підходи до діагностики, профілактики та лікування папіломавірусної інфекції / В. К. Чайка, А. В. Чайка, О. М. Носенко [та ін.] // Медико-соціальні проблеми сім'ї. - 2010. - Т. 15, № 1. - С. 67-75.

24. Ho G. Y. Natural history of cervicovaginal papillomavirus infection in young women / G. Y. Ho, R. Bierman, L. Beardsley [et al.] // N. Engl. J. Med. 1998. - Vol. 338. - P. 423-428.

25. Natural history of cervical human papillomavirus infection in young women: a longitudinal cohort study $/$ C. B. Woodman, S. Collins, H. Winter [et al.] // Lancet. 2001. - Vol. 357(9271). - P. 1831-1836.

26. Роговская С. И. Папилломавирусная инфекция у женщин и патология шейки матки./ С. И. Роговская. - М. : Издательская группа «ГЭОТАР - Медиа», 2005. - С. 48 - 67.

27. Европейский курс по заболеваниям, ассоциированным с ВПЧ: рекомендации для врачей общей практики по диагностике и лечению аногенитальных бородавок / Г. ван Крог, С. Дж. Н. Лейси, Г. Гросс [и др.] // ИППП.- 2001.- № 1.- С. 5 - 13.

28. Ковалев М. И. Низкоинтенсивное и высокоэнергетическое лазерное излучение в акушерстве и гинекологии / М. И. Ковалев. - М., 2000. - 173 с.

29. Лапкын К. В. Первый опыт применения радиохирургического прибора “Сургитрон» в хирургии органов билиопанкреатодуоденальной зоны / К. В. Лапкын // В сб. : Актуальные вопросы хирургической гепатологии. - Томск, 1997.- 159 с.

30. Применение активатора противовирусного иммунитета в комплексной терапии рецидивирующих остроконечных кондилом / Ю. Н. Перламутров, А. М. Соловьев, Р. Р. Атауллаханов [и др.] // Иммунопатол. Аллергол. Инфектол. - 2003. - № 3.
31. Роговская С. И. Папилломавирусная инфекция у женщин и патология шейки матки / С. И. Роговская. - М. : Издательская группа «ГЭОТАР - Медиа», 2005. - С. 48 - 67.

32. Показники інтерферонового статусу та продукції фактора некрозу пухлин у юних жінок із запальними захворюваннями внутрішніх статевих органів / А. В. Руденко, О. В. Ромащенко [та ін.] // Імунологія та алергологія. - 2000. - № 2-3. - С. 43-47.

33. Baseline cytology, human papillomavirus testing, and risk for cervical neoplasia: a 10-year cohort analysis $/$ M. E. Sherman, A. T. Lorincz, D. R. Scott [et al.] // J. Natl. Cancer. Inst. - 2003. - Vol. 95. - P.46-52.

34. The prevalence of human papillomavirus type 16 DNA sequences in cervical intraepithelial neoplasia and invasive carcinoma of the cervix / D. J. McCance, M. J. Campion, P. K. Clarkson [et al.] // Br. J. Obstet. Gynaecol. - 1985. - № 92. - P. 1101 - 1105.

35. Yang B. Vulvar intraepithelial neoplasia of the simplex (differentiated) type: a clinicopathologic study including analysis of HPV and p53 expression / B. Yang, W. R. Hart // Am. J. Surg. Pathol. - 2000. - Vol. 24, № 3. - P. 429 - 441.

36. Epidemiology and natural history of human papillomavirus infections and type-specific implications in cervical neoplasia / F. X. Bosch, A. N. Burchell, M. Schiffman [et al.] // Vaccine. - 2008. - Vol.26. P.1-16.

37. Grading the severity of cervical neoplasia based on combined histopathology, cytopathology, and HPV genotype distribution among 1,700 women referred to colposcopy in Oklahoma / N. Wentzensen, M. Schiffman, S. T. Dunn [et al.] // Int. J. Cancer. - 2009. - Vol. 124. P. 964-969.

38. Human papillomavirus infections with multiple types and risk of cervical neoplasia / H. Trottier, S. Mashmud, M. C. Costa [et al.] // Cancer Epidemiol Biomarkers Prev. - 2006. - Vol. 15. - P. 1274 1280.

39. Булавина Н. Г. Опыт применения хирургического лазера при лечении фоновых и предраковых заболеваний шейки матки / Н. Г. Булавина, И. Г. Меленюк, Л. Г. Баженова // Медицина в Кузбассе. 2006. - № 1. - С. 130-131.

40. Маникевич К. В. Эффективность лазеродеструкции у больных с эктопией шейки матки при носительстве папилломавирусной инфекции / К. В. Маникевич // Уч. зап. СПбГмУ им. акад. И. П. Павлова. - СПб., 2005. - С. 87.

41. Зелинский А. А. Опыт применения лазерного коагулятора «Лика-хирург» с длиной волны 1470 нм в лечении фоновых заболеваний шейки матки / А. А. Зелинский, Н. Н. Настрадина // Жіночий лікар. 2013. - № 2. - С. 18-21.

42. Применение хирургических диодных лазеров в гинекологии / [В. В. Семенов, О. С. Севостьянова, Ю. Н. Голоденко и др.]. - Черкассы : Вертикаль, издатель С. Г. Кандыч, 2011. - 40 с.

43. Порівняння ефективності та безпечності використання лазерного і радіохвильового випромінювання при лікуванні патології шийки матки / В. В. Семенов, О. С. Севостьянова, Ю. Н. Голоденко [та ін.] // Жіночий лікар. - 2012. - № 3. - С. 44. 